\section{Viktig og spennende om medisinsk undervisning}

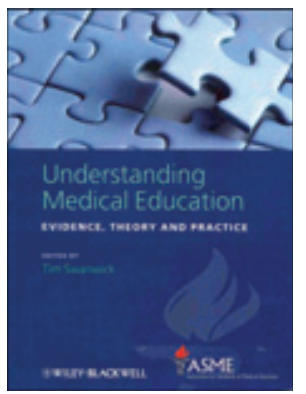

Tim Swanwick, red. Understanding medical education

Evidence, theory and practice. 446 s, tab, ill. Chichester: Wiley-Blackwell, 2010. Pris GBP 40

ISBN 978-1-4051-9680-2

Denne utgivelsen er resultat av et samarbeid mellom sentrale fagfolk innen medisinsk undervisning i Storbritannia og Nord-Amerika. Gjennom 29 kapitler gjennomgår forfatterne medisinsk pedagogikk og design av studieplan, samt evaluering i ulike former og forskning på medisinsk undervisning. 59 medisinske undervisere og undervisningsledere har bidratt, og i alle kapitlene viser man til tung dokumentasjon. Kapitlene er laget over en felles lest. De starter med hovedbudskap (key messages) som med få ord viser hva kapitlet inneholder, og som ofte setter tankene i sving og inviterer til videre lesning. Teksten er illustrert med tabeller og figurer som utdyper budskapet eller setter det i relieff. De fleste kapitlene er åpenbart nyskrevne og ofte provokative i sin vinkling.

Undertittelen angir tema: Evidence, theory and practice. Hva er så evidens innen pedagogisk forskning? Kapitlet om kvantitativ forskning er skrevet av Geoff Norman og Kevin Eva ved McMaster University. De er begge tunge og meningsbærende forskere innen medisinsk undervisning, og med styrke hevder de at det vanlige designhierarkiet ikke gjelder innen forskning på medisinsk undervisning. De flagger at verdien av kritiske, syntetiserende, teoretisk orienterte og empiribaserte oversiktsartikler ikke kan overvurderes. Forfatternes søkelys, rettet mot triangulering og teoriforankring/ teoristyring av pedagogisk forskning, er viktig og i tråd med løpende diskusjoner i feltet.

Det bringer meg til det andre angitte temaet: pedagogiske teorier. David Kaufman og Karen Mann skriver et tankevekkende kapittel om hvordan de ulike pedagogiske teoriene peker mot ulike didaktiske praksiser. Forfatterne beskriver hvordan utgangspunktet har flyttet seg fra synet på at læreren skal gi studenten noe (behaviorisme), via vektlegging av det lærende individet (konstruktivisme), til fokus på at individ og miljø lærer av hverandre i sosial interaksjon (situert læring). Det forelesningsbaserte studiet, men også det Bologna-baserte rammeverket, ligger nærmest behaviorismen, mens problembasert lærings (PBL)-pedagogikk ligger nærmest (sosial) konstruktivisme. Forfatterne hevder at bare teorien om situert læring adresserer alle viktige læringsfaktorer ved klinisk undervisning.

Begrepet situert læring utdypes videre av Clare Morris og David Blaney i kapitlet om arbeidsplassbasert læring (work-based learning). Vi tenker vanligvis at klinisk eksposisjon inngår i studieplanen, mens dette kapitlet viser hvordan man kan la klinisk arbeid vare studieplanen. Forfatterne baserer seg på teorier om situert læring og skisserer hvordan slik læring kan foregå. Her er vi ved frontlinjen i utviklingen av medisinsk undervisning; teoriene er solide og grundig utviklet, men dokumentasjonen foreløpig sparsom.

I sin helhet gir forfatterne omfattende dokumentasjon av de ulike sidene ved medisinsk pedagogikk og undervisning, og boken er den mest interessante på lenge innen dette feltet. Den vil etter alle solemerker være flaggskipet i mange år for utgiverne; Association for the Study of Medical Education (ASME).

\section{Anders Bærheim}

Faggruppe for allmennmedisin

Universitetet i Bergen

\section{Om læring og undervisning til å bli klok av}

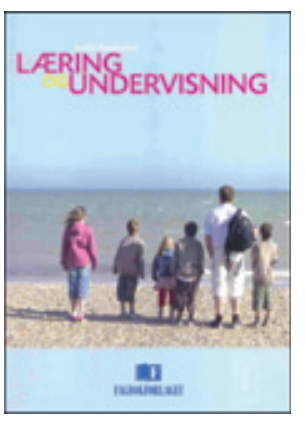

\section{Arild Raaheim \\ Læring og undervisning}

182 s, tab, ill. Bergen: Fagbokforlaget, 2010. Pris NOK 298

ISBN 978-82-450-1113-5

Arild Raaheim er kognitiv psykolog og professor i universitetspedagogikk ved Universitetet i Bergen. I tillegg er han - bedømt ut fra denne boken - et klokt menneske som makter å integrere vitenskapelighet med erfaringsbasert kunnskap og humanisme. Han har omfattende erfaring, både forskningsmessig og praktisk, med høyere utdanning. Raaheim sier at han har liten sans for «merkelapp-pedagogikk», hvor det viktigste er hvilken teoretisk retning man hører til. Det merkes i fremstillingen, noe som er til glede for leseren.

Foranledningen til å skrive boken er at det innen utgangen av 2012 skal innføres et nasjonalt kvalifikasjonsrammeverk for høyere utdanning. Denne typen av byråkratiske ovenfra og nedad-reformer av utdanning kan lett ende opp med flotte ord i festtaler og planer, men lite forandring av utdanningens virkelighet. Studieplaner og beskrivelser blir endret, men ofte er studentenes læring uforandret eller kanskje til og med dårligere enn før. En årsak er nok passiv motstand i miljøene som skal sette initiativene ut i livet - universitetslærere ser lett bare den byråkratiske styringsiveren og ikke de tross alt fornuftige intensjonene bak. Fremfor å tenke på hvordan man kan bruke dette til å forbedre utdanningen man er en del av, gjennomfører man de nødvendige endringene som papirøvelser uten innlevelse og entusiasme. Denne boken er en god hjelp til å snu på en slik reaksjonsmåte, selv om Raaheim (med god grunn) er skeptisk til en del av tankegangen bak kvalifikasjonsrammeverket.

Forfatterens perspektiv er nedenfra og oppover: sett fra læringssituasjonen og studentens ståsted. Det betyr at psykologiske og pedagogiske forskningsresultater og teorier presenteres i relevante, konkrete sammenhenger som det er lett å kjenne seg igjen i for en universitetslærer. Det betyr også at undervisningspraksis vurderes kritisk i et læringsperspektiv: «Faktum er at svært mye av den praksis vi ser på dette feltet bryter med, eller $\mathrm{i}$ alle fall unnlater å ta hensyn til, mye av det vi vet om læring» (s. 46). Han presiserer også at «... all undervisning må starte med et spørsmål om hva læring er, og hva det vil si å ha kunnskap i akkurat dette faget» (s. 2). Dette burde være selvsagt, men er det dessverre ikke - altfor ofte er undervisningen et mål i seg selv.

Raaheims pedagogiske filosofi er enkel og spissformuleres tidlig: Det finnes ingen læringsoppgave som er så vanskelig at ikke alle kan løse den under forutsetning av at de a) er motivert, b) blir møtt med respekt av et utfordrende læringsmiljø og c) har et visst minimum av evner. Han setter derved også agendaen for oppbygningen og tematikken. Første del dreier seg for en stor del om forutsetninger for læring, hvor en dypere forståelse av motivasjon står sentralt og får stor oppmerksomhet. Tap av motivasjon drøftes inngående i forbindelse med frafallsproblematikk. Raaheim diskuterer intelligensbegrepet og myten om en sterk sammenheng mellom (medfødte) evner og akademiske prestasjoner. Et annet tema som går igjen, er om dagens undervisnings- og eksamenspraksis i tilstrekkelig grad bidrar til at studenter utvikler evne til selvstendig, kritisk analyse av kunnskap og egen praksis. Han stiller også kritiske spørsmål ved det kunnskapssynet studentene utvikler gjennom tradisjonelle universitetsstudier.

I tråd med den overordnede filosofien behandler forfatteren inngående samspillet mellom læringsmiljøet og den lærende. Her drøfter han også begrepet «forskningsbasert undervisning». 
Raaheim gir dette en utradisjonell tolkning: «Forskningsbasert undervisning er undervisning som tar hensyn til og bygger på det forskning har vist fører til god læring.» At dette aspektet aldri kommer opp i diskusjoner om forskningsbasert undervisning (slik jeg har hørt dem), sier nok noe om forskeres manglende nysgjerrighet på hvordan læring egentlig foregår. Fra egne erfaringer er jeg helt enig med Raaheims formulering om at det er et tankekors at så mange forskere har en så uvitenskapelig tilnærming til det som utgjør en vesentlig del av jobben.

Andre viktige temaer tar forfatteren opp underveis. For eksempel diskuterer han fusk og plagiering ganske inngående og nyansert. Eksamen og dens styrende virkning på studentenes læring drøftes grundig, og en del myter avlives. Hvordan en læreplan bør bygges opp - igjen ut fra et læringsperspektiv - behandles også innsiktsfullt. Forfatteren avslutter med å drøfte hva som kjennetegner god undervisning, selvfølgelig sett i et lærings- fremfor et lærerperspektiv. To enkle forhold blir stående helt sentralt når det gjelder hva som karakteriserer en god underviser: Han eller hun bryr seg om studentene og er opptatt av faget. Det er ikke nok med bare det ene, men når begge er på plass, kan studentene tilgi mye som ikke er perfekt.

Arild Raaheims bok er en hjelp til å gjøre noe konstruktivt ut av den anledningen kvalifikasjonsrammeverket gir til en gjennomgang av våre universitetsutdanninger. Det er aldri bortkastet å arbeide med å formulere hva vi vil med studiene og studentene. Men boken er først og fremst et frittstående innlegg i debatten om hva som gir best læring, og om sammenhengen mellom mål og metode i utdanning. Man kan drømme om at skolepolitikere tar seg tid til å lese og ta innholdet inn over seg. Den bør i alle fall leses av alle som gjennomgår pedagogisk basisutdanning ved universitetene. Men aller mest ville jeg ønske at den ble lest og fordøyd av alle de av oss som - uansett alder - har ansvar for å legge til rette for universitetsstudenters læring og utvikling.

\section{Per Brodal}

Institutt for medisinske basalfag

Universitetet i Oslo

\section{Godt kompendium}

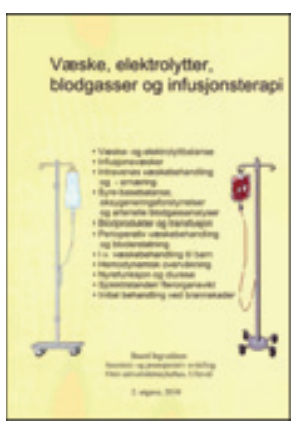

Baard Ingvaldsen

Væske, elektrolytter blodgasser og infusjonsterapi

2. utg. 271 s, ill. Oslo: Eget forlag, 2010

Pris NOK 300

ISBN 978-82-303-1617-7

Denne utgivelsen omfatter en rekke fagområder som leger og sykepleiere, som behandler alvorlige syke pasienter, bør beherske. Uansett sykdom kan det være behov for væsketerapi og bruk av blodprodukter. Det kan også være elektrolytt- og syre-base-forstyrrelser som må vurderes og korrigeres. Dette er emner som kan være lite undervist i grunnstudier, og hvor mange har vanskeligheter med å omsette teoretisk kunnskap til praktisk medisin.

På en lettfattelig måte presenterer forfatteren den nødvendige teorien og praktiske anbefalinger om hvordan man skal vurdere og behandle ubalanse i elektrolyttstatus og væskebalanse, i tillegg til syre-base-forstyrrelser. Disse delene er spesielt vellykket og gir mye kunnskap. En fordel er også at han gir en oppdatering i norsk praksis på fagfeltet.

Forfatteren går kort gjennom bruk av blodprodukter. Til slutt penser han inn på vurdering og behandling av respirasjonsforstyrrelser og hemodynamiske forstyrrelser. Dette bør leseren se på som en kort innføring, og man bør lese mer detaljert litteratur hvis man vil ha god inn- sikt i temaene. Ingvaldsen uttrykker da også dette selv i forordet.

De som er interessert $\mathrm{i}$ avansert utforming av sideoppsett, gode illustrasjoner, fine bilder eller eksklusiv innbinding, bør finne annen litteratur. Formatet er mer som et kompendiehefte. Men at boken er enkelt laget går ikke utover klarhet i presentasjon og formidling av kunnskap.

Målgruppene er mange. Selv har jeg anbefalt den til bruk i utdanning av intensiv- og anestesisykepleiere og til medisinstudenter. Den er også svært godt egnet som en oppdatering for leger på sykehus. Innen alle spesialiteter vil det, for å behandle innlagte pasienter, være nødvendig å ha grunnleggende innsikt i nettopp de emnene denne boken omfatter.

Pål Klepstad

Intensivavdelingen

St. Olavs hospital

\section{Smilende studieteknikk}

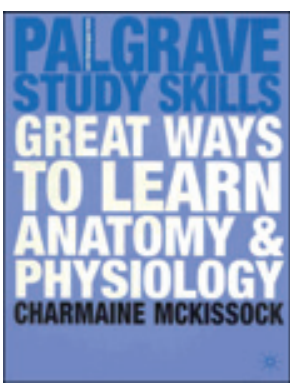

Charmaine McKissock

Great ways to learn anatomy and physiology 192 s, ill. Basingstoke: Palgrave Macmillan, 2009. Pris GBP 16 ISBN 978-0-230-20991-6

Målgruppen for denne selvhjelpsboken i studieteknikk er primært, men ikke utelukkende, studenter med spesifikke lærevansker (leseog skrivevansker og/eller matematikkvansker). Konvensjonelle råd som kan bidra til bedre studieteknikk er fremstilt på en uhøytidelig måte og illustrert med egenproduserte humoristiske tegninger. Det er også verdifullt at forfatteren fremhever at mennesker er svært forskjellige, og hvor viktig det er å velge den læringsformen som passer best for en selv.

Et mindre heldig valg er at anatomi og fysiologi er brukt som eksempler i så stort omfang at fremstillingen får preg av en minilærebok i disse fagene, uten at forfatteren har tilstrekkelig kompetanse i anatomi eller fysiologi til å lykkes. Anatomi og fysiologi er fremstilt uinspirert og kjedelig i form av lister og skjemaer, til dels med store feil og mangler. Tegningen på side 61 mangler f.eks. leveren i en samlet oversikt over fordøyelsesprosessene, og vann synes å kunne gå fra tarm til nyre uten først å passere blod og lever.

Anatomi og fysiologi er en utfordring for alle nye studenter. I tillegg kan studenter med lese- og skrivevansker få spesielle utfordringer med navn på anatomiske strukturer. Studenter med matematikkvansker kan få spesielle utfordringer med diagrammer i fysiske og kjemiske forklaringer på fysiologiske prosesser. Forfatteren vil gjerne hjelpe, men lykkes bare delvis. Som bok i studieteknikk dekker den mange av de samme temaene som mer konvensjonelle valg (1), men den gjør det på en mer underholdende måte. Det anatomiske og fysiologiske stoffet er springende og mangelfullt i forhold til undervisningen i første del av fellessemestrene i ernæring, odontologi og medisin ved Universitetet i Oslo. Det kan imidlertid komme mye god læring ut av å finne feilene i en læreboktekst.

\section{Arild Njå}

Avdeling for fysiologi

Institutt for medisinske basalfag

Universitetet i Oslo

\section{Litteratur}

1. Wilhelmsen LS, Manger T. Effektiv læring: et hefte ved studiestart for alle nye studenter. Bergen: Fagbokforlaget, 2005. 